ARTICLE

Received 29 May 2013 | Accepted 8 Nov 2013 | Published 6 Dec $2013 \quad$ DOl: 10.1038/ncomms3908

\title{
Rapid interhemispheric climate links via the Australasian monsoon during the last deglaciation
}

Linda K. Ayliffe ${ }^{1}$, Michael K. Gagan', Jian-xin Zhao ${ }^{2}$, Russell N. Drysdale ${ }^{3,4}$, John C. Hellstrom ${ }^{5}$, Wahyoe S. Hantoro ${ }^{6}$, Michael L. Griffiths ${ }^{7}$, Heather Scott-Gagan', Emma St Pierre ${ }^{2}$, Joan A. Cowley ${ }^{1}$ \& Bambang W. Suwargadi6

Recent studies have proposed that millennial-scale reorganization of the ocean-atmosphere circulation drives increased upwelling in the Southern Ocean, leading to rising atmospheric carbon dioxide levels and ice age terminations. Southward migration of the global monsoon is thought to link the hemispheres during deglaciation, but vital evidence from the southern sector of the vast Australasian monsoon system is yet to emerge. Here we present a 230 thorium-dated stalagmite oxygen isotope record of millennial-scale changes in AustralianIndonesian monsoon rainfall over the last 31,000 years. The record shows that abrupt southward shifts of the Australian-Indonesian monsoon were synchronous with North Atlantic cold intervals 17,600-11,500 years ago. The most prominent southward shift occurred in lock-step with Heinrich Stadial 1 (17,600-14,600 years ago), and rising atmospheric carbon dioxide. Our findings show that millennial-scale climate change was transmitted rapidly across Australasia and lend support to the idea that the 3,000-year-long Heinrich 1 interval could have been critical in driving the last deglaciation.

\footnotetext{
${ }^{1}$ Research School of Earth Sciences, The Australian National University, Canberra, ACT 0200, Australia. ${ }^{2}$ School of Earth Sciences, The University of Queensland, Brisbane, QLD 4072, Australia. ${ }^{3}$ Department of Resource Management and Geography, The University of Melbourne, Parkville, VIC 3010, Australia. ${ }^{4}$ EDYTEM, UMR CNRS 5204, Université de Savoie 73376, Le Bourget du Lac cedex, France. ${ }^{5}$ School of Earth Sciences, The University of Melbourne, Parkville, VIC 3010, Australia. ${ }^{6}$ Research Center for Geotechnology, Indonesian Institute of Sciences, Bandung 40135, Indonesia. ${ }^{7}$ Department of Environmental Science, William Paterson University, Wayne, New Jersey 07470, USA. Correspondence and requests for materials should be addressed to M.K.G. (email: Michael.Gagan@anu.edu.au).
} 
T he last deglaciation was the final stage in the most recent of the $\sim 100,000$-year cycles of global ice sheet growth and decay. Palaeoclimate records ${ }^{1-7}$ and modelling studies ${ }^{8-11}$ have led to an emerging hypothesis for glacial terminations whereby rapid reorganization of the ocean and atmospheric circulation serves to link millennial-scale cooling in the North Atlantic with deglacial global warming. A key part of the proposed climatic chain of events ${ }^{5}$ involves southward displacement of the global monsoon system and Southern Hemisphere westerly wind belt in response to Northern Hemisphere cooling, which in turn drives upwelling and $\mathrm{CO}_{2}$ ventilation from the Southern Ocean, and thus deglacial warming. Under this scenario, protracted North Atlantic cooling and strong southward displacement of the global monsoon during Heinrich Stadial 1 (HS1, 18-15 kyr BP, thousand years before $1950 \mathrm{AD}$ ) may have been pivotal in driving the last deglaciation. Consistent with this hypothesis, terrestrial palaeoclimate records show that substantial weakening of the southeast Asian monsoon during HS1 (refs 12-15) was accompanied by anti-phased strengthening of the South American monsoon ${ }^{16,17}$, but weakening of the summer monsoon in southern Africa $^{18}$.

The Australasian monsoon system, with the Indo-Pacific warm pool, could have played a key role in deglacial warming because deep atmospheric convection above this large maritime region is a fundamental driver of Earth's atmospheric circulation. However, marine and terrestrial records of the climatic footprint of HS1 in the Southern Hemisphere sector of the Australasian monsoon are still sparse, and not entirely consistent ${ }^{19-24}$. Marine records of riverine input to the Flores $\mathrm{Sea}^{23}$ and offshore of southern Papua New Guinea ${ }^{22}$ indicate increased runoff during Northern Hemisphere cold intervals such as HS1. Terrestrial evidence for increased rainfall during HS1 is also found in lake records and a speleothem record for northern Australia ${ }^{20,24}$. However, deep-sea sediment faunal records reflecting monsooncontrolled austral winter upwelling off the southern coast of $\mathrm{Java}^{21}$ suggest drier conditions during HS1.

In the past decade, precisely dated records of oxygen isotope ratios $\left(\delta^{18} \mathrm{O}\right)$ in stalagmites (cave carbonate formations) from China have provided histories of East Asian summer monsoon (EASM) rainfall variability since $390 \mathrm{kyr} \mathrm{BP}$ and substantiated links between North Atlantic cooling and southward displacement of the $\mathrm{EASM}^{4,12,13}$. Likewise, stalagmites from Borneo have documented northern equatorial climate change from 570 to $210 \mathrm{kyr} \mathrm{BP}{ }^{25}$ and over the last $100 \mathrm{kyr}^{14,15}$. Stalagmite $\delta^{18} \mathrm{O}$ records of the Australian-Indonesian summer monsoon (AISM), however, are still discontinuous and limited to the last $40 \mathrm{kyr}^{24,26,27}$.

Here we present new $\delta^{18} \mathrm{O}$ records for five ${ }^{230} \mathrm{Th}$ dated stalagmites from Liang Luar cave on the island of Flores, southcentral Indonesia $\left(8^{\circ} 32^{\prime} \mathrm{S}, 120^{\circ} 26^{\prime} \mathrm{E}\right)$, located in the Southern Hemisphere sector of the Australasian monsoon system (Fig. 1). Comparison of the $31 \mathrm{kyr} \delta^{18} \mathrm{O}$ record of AISM rainfall for Flores with EASM rainfall in China reveals synchronous millennial-scale southward displacement of the entire Australasian monsoon system during North Atlantic cold intervals. The largest southward shift in this north-south precipitation seesaw pattern occurred during the HS1 interval (17.6 to $14.6 \mathrm{kyr}$ BP). The prominence of the HS1 climatic footprint across Australasia supports the possibility that it played a key role in the sequence of events that drove the last deglaciation.

\section{Results}

Cave attributes. Liang Luar is an $\sim 1,700$-m-long stream passage cave $\sim 550 \mathrm{~m}$ above sea level that formed in marine limestone of late Miocene age. The new stalagmite $\delta^{18} \mathrm{O}$ records, and those generated for previous studies ${ }^{26,27}$, come from specimens collected $\sim 500-900 \mathrm{~m}$ from the entrance where narrow passageways restrict airflow and maintain stable cave temperatures $\left(\sim 24.5^{\circ} \mathrm{C}\right)$ and high relative humidity. Mean annual rainfall at the cave site is $1,200 \mathrm{~mm}$ with $\sim 70 \%$ falling during the austral summer wet season (December-March), under the influence of the northwest monsoon ${ }^{26}$, while $\sim 30 \%$ is related to easterly trade wind-induced orographic rainfall in austral winter. The location of Liang Luar near the current southern limit of the Intertropical Convergence Zone (ITCZ) makes it ideally situated to record millennial-scale climate change in the AISM region (Fig. 1).

Speleothem $\delta^{18} \mathrm{O}$ records. A total of $86^{230} \mathrm{Th}$ dates for the five stalagmite $\delta^{18} \mathrm{O}$ records provides excellent continuous chronological control over the last 23.9 kyr (Supplementary Figs

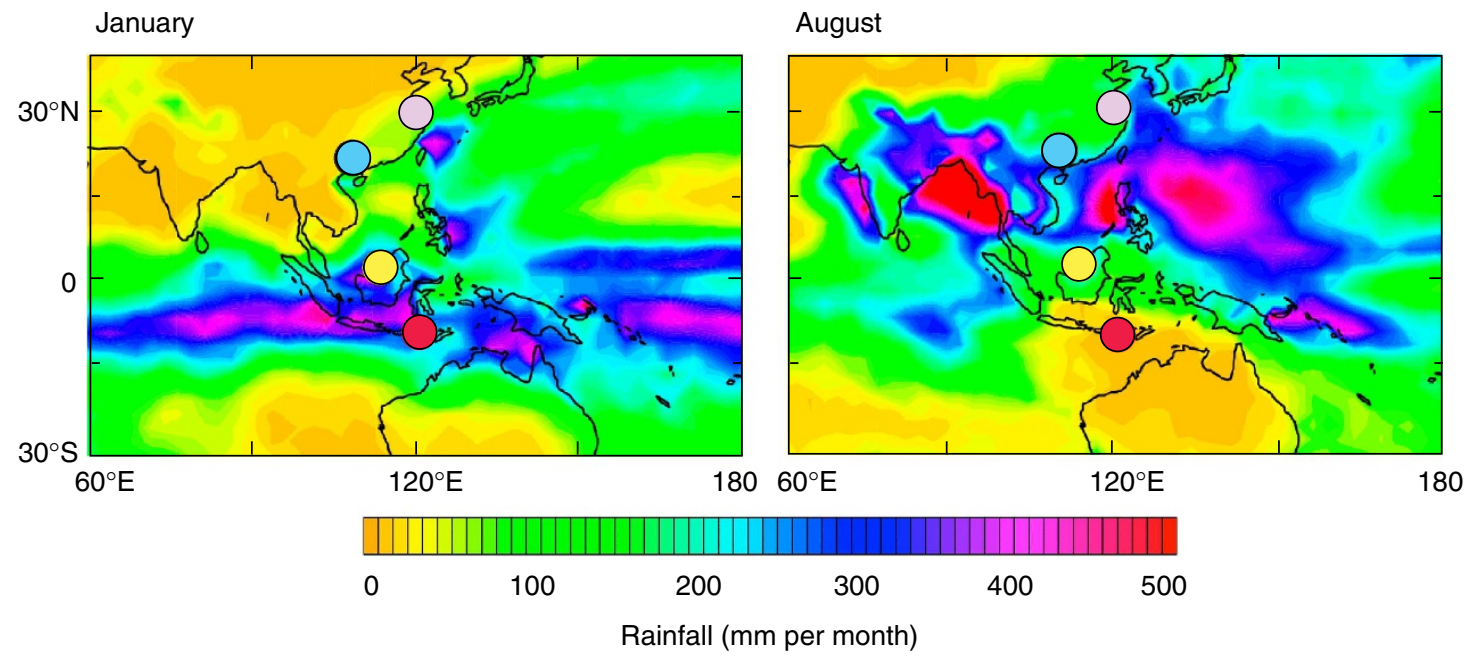

Figure 1 | Present-day monsoon seasonality in Australasia and study location. Colour coding on map shows average rainfall rates (mm per month) for January (peak of the AISM) and August (peak of the EASM) between 1979 and 1991. The average seasonal position of the Intertropical Convergence Zone can be inferred from the locus of maximum rainfall. The rainfall data (gridded at $2.5 \times 2.5$ degree resolution) are from ref. 49 based on their analysis of land-based rain-gauge measurements ${ }^{50}$ and ocean precipitation estimates from the Microwave Sounding Unit (MSU) ${ }^{51}$. Circles show locations of Liang Luar, west Flores $\left(8^{\circ} 32^{\prime} \mathrm{S}, 120^{\circ} 26^{\prime} \mathrm{E}\right.$, red) and other cave sites referred to in the text: Gunung Buda, north Borneo $\left(4^{\circ} \mathrm{N}, 114^{\circ} \mathrm{E}\right.$, yellow), Dongge cave, south China $\left(25^{\circ} 17^{\prime} \mathrm{N}, 108^{\circ} 25^{\prime} \mathrm{E}\right.$, blue) and Hulu cave, east China $\left(32^{\circ} 30^{\prime} \mathrm{N}, 119^{\circ} 10^{\prime} \mathrm{E}\right.$, pink). 
S1-S5). Age corrections for detrital thorium are generally very small for the Liang Luar stalagmites (Supplementary Table S1). The average precision for ${ }^{230} \mathrm{Th}$ ages encompassing important deglacial millennial-scale climate change is $\pm 0.9 \%(2 \sigma)$. Good reproducibility of millennial-scale features across overlapping growth intervals in the stalagmite $\delta^{18} \mathrm{O}$ profiles confirms that the effects of any disequilibrium isotope fractionation and recrystallization of calcite are negligible (Fig. 2, Supplementary Fig. S6). Moreover, poor correlation between $\delta^{18} \mathrm{O}$ and $\delta^{13} \mathrm{C}$ in the stalagmites indicates minimal kinetic fractionation of isotopes (Supplementary Fig. S7). We note that stalagmite LR06-C5 contains 22-66\% aragonite between 19.4 and $17.5 \mathrm{kyr}$ BP (Supplementary Table S2). However, the $\delta^{18} \mathrm{O}$ record for stalagmite LR06-C5, after correction to magnesium calcite-equivalent $\delta^{18} \mathrm{O}$ values (Supplementary Fig. S8), is in good agreement with the record for stalagmite LR06-C6 across their interval of overlap (Fig. 2). Therefore, the effects of non-climate related processes are small, thus the millennial-scale features in the Liang Luar $\delta^{18} \mathrm{O}$ record can be interpreted in terms of changes in the cave environment.

We interpret millennial-scale changes in the stalagmite $\delta^{18} \mathrm{O}$ records to primarily reflect changes in the $\delta^{18} \mathrm{O}$ of rainfall, and thus AISM intensity. Analysis of modern rainfall $\delta^{18} \mathrm{O}$ at Liang Luar $^{26}$ shows that summer monsoon rainwater is depleted in ${ }^{18} \mathrm{O}$ by $6-7 \%$ compared with rainwater for the remainder of the year. This large isotopic contrast means that changes in the amount of summer rainfall, or the fraction of the year dominated by the northwest monsoon, produce a significant shift in the $\delta^{18} \mathrm{O}$ of Flores rainfall. Today, the position of the ITCZ governs the balance between summer monsoon rain and winter trade windinduced orographic rainfall, and hence $\delta^{18} \mathrm{O}$ at Flores. Waterisotope-enabled climate models show that similar relationships between ITCZ positioning and rainfall $\delta^{18} \mathrm{O}$ also prevailed at

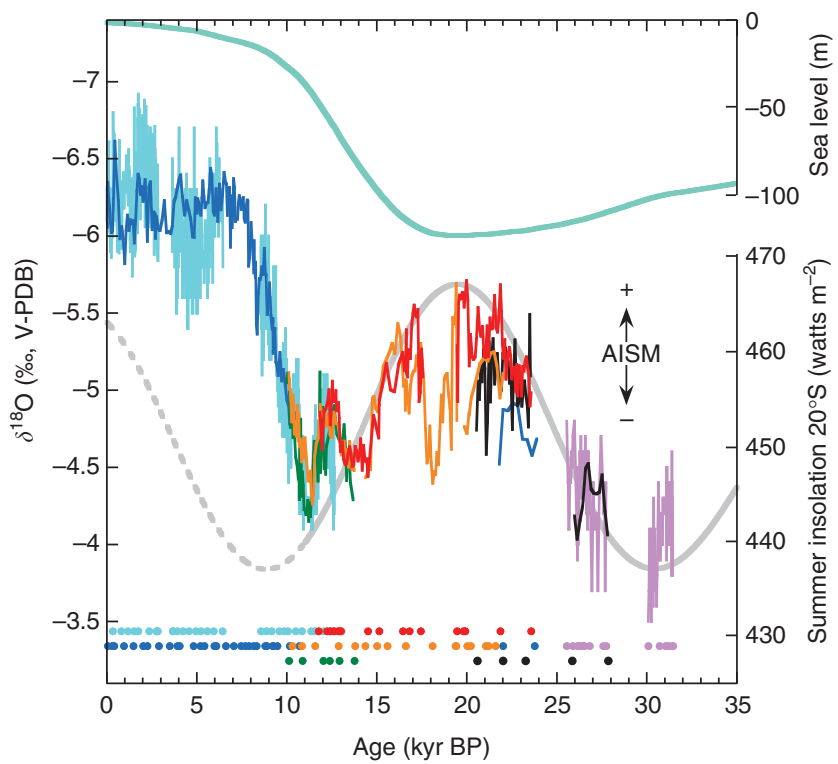

Figure 2 | Liang Luar stalagmite $\boldsymbol{\delta}^{\mathbf{1 8}} \mathbf{O}$ records over the past $\mathbf{3 1}$ kyr. $\delta^{18} \mathrm{O}$ records for stalagmites LR06-C2 (green), LR06-C3 (black), LR06-C5 (orange), LR06-C6 (red), LR06-B1 (light blue) ${ }^{26}$, LR06-B3 (dark blue), and LR06-E1 (light purple) ${ }^{27}$ are compared with summer insolation (205; grey) and sea level (pale green). Arrow depicts the direction of a stronger $(+)$ or weaker $(-)$ AISM. ${ }^{230}$ Th ages at the bottom of the plot are colour-coded by stalagmite (Supplementary Table S1). The dashed portion of the insolation curve indicates when rising sea levels ${ }^{52}$ flooded the emergent Sunda and Sahul shelves, thus changing the factors controlling rainfall $\delta^{18} \mathrm{O}$ at Flores.
Flores during the last glacial ${ }^{27}$. Millennial-scale changes in warm pool temperatures (and surface air temperature) were small over the last $23 \mathrm{kyr}^{28}$, thus changes in the $\delta^{18} \mathrm{O}$ of rainfall, rather than temperature, dominate the record.

Orbital-scale variability. Long-term changes in the Flores $\delta^{18} \mathrm{O}$ record from 31 to $11 \mathrm{kyr}$ BP track changes in local austral summer insolation (Fig. 2). The lowest $\delta^{18} \mathrm{O}$ values (indicative of a strong AISM) coincide with the austral summer insolation maximum at $\sim 20 \mathrm{kyr} B P$. Similar covariations of stalagmite $\delta^{18} \mathrm{O}$ with local summer insolation are evident in records for China ${ }^{4,12}$ and Brazil ${ }^{29}$. The new Flores record demonstrates the strong positive influence of insolation seasonality on monsoon rainfall in the Indonesian maritime region when the land area was greater during the Last Glacial Maximum (LGM), but warm pool temperatures were $3-4{ }^{\circ} \mathrm{C}$ cooler than at present ${ }^{28}$. Furthermore, adjustment of the Flores $\delta^{18} \mathrm{O}$ record for the effect of ice volumerelated changes in the $\delta^{18} \mathrm{O}$ of seawater indicates that the LGM around Flores may have been as wet as the Holocene (Supplementary Fig. S9). Most of the available palaeoclimate records for the near-equatorial centre of the Australasian monsoon system suggest drier conditions during the $\mathrm{LGM}^{30}$, in contrast to our finding of wetter LGM conditions further south. Our results are consistent with marine sediment archives off South Java showing Australian-Indonesian winter monsoon upwelling at its weakest during the LGM in response to southward displacement of the ITCZ ${ }^{21}$. After $11 \mathrm{kyr} \mathrm{BP}$, the Flores $\delta^{18} \mathrm{O}$ record decouples from insolation forcing in response to Holocene flooding of the Sunda and Sahul shelves ${ }^{26}$.

Millennial-scale variability. Following the LGM, the Flores $\delta^{18} \mathrm{O}$ record is punctuated by a series of abrupt millennial-scale events from 17.6 to $11.5 \mathrm{kyr}$ BP (Fig. 3). Precise radiometric dating shows that they were synchronous, and anti-phased, with well-

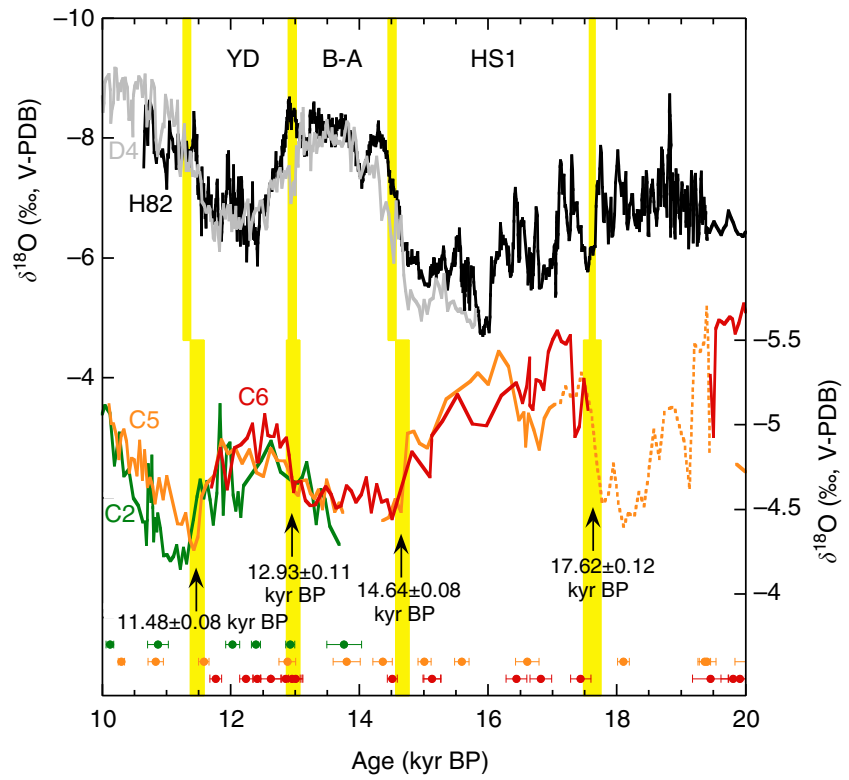

Figure 3 | Anti-correlation between climate change in Flores and China. $\delta^{18} \mathrm{O}$ time-series for stalagmites from Liang Luar (LR06-C2: green, LR06C5: orange, LR06-C6: red) and China (Hulu cave: black ${ }^{12,47,48}$, Dongge cave: grey ${ }^{13}$ ). Yellow bars indicate the timing and duration of the HS1, B-A and YD climatic shifts in Flores (lower curves) and China (upper curves) (Supplementary Fig. S10). Colour-coded ${ }^{230}$ Th ages (with $2 \sigma$ errors indicated by bars) are shown below each of the Liang Luar stalagmite $\delta^{18} \mathrm{O}$ records. 
documented counterpart events in stalagmite $\delta^{18} \mathrm{O}$ records of EASM rainfall in China ${ }^{12,13}$ (Supplementary Fig. S10). The cold HS1 interval in the North Atlantic is marked by a stronger AISM in Flores (17.6 \pm 0.1 to $14.6 \pm 0.1 \mathrm{kyr} \mathrm{BP})$ and weaker EASM in China ( $17.6 \pm 0.1$ to $14.5 \pm 0.1 \mathrm{kyr} \mathrm{BP})$. The response of the Australasian monsoon system to the warmer Bølling-Allerød interval is opposite, with a weaker AISM in Flores (14.6 \pm 0.1 to $12.9 \pm 0.1 \mathrm{kyr} B P)$ and stronger EASM in China (14.5 \pm 0.1 to $13.0 \pm 0.1 \mathrm{kyr} \mathrm{BP})$. This is followed by a stronger AISM in Flores (12.9 \pm 0.1 to $11.5 \pm 0.1 \mathrm{kyr} \mathrm{BP})$ and an opposing weakening of the EASM in China ( $13.0 \pm 0.1$ to $11.3 \pm 0.1 \mathrm{kyr} \mathrm{BP})$ during the cooler Younger Dryas interval. A sharp reduction in rainfall over Flores around 19-18 kyr BP has no clear counterpart event in China, but the signal is anti-phased with a generally stronger EASM when North Atlantic sea surface temperatures were relatively warm prior to the HS1 interval ${ }^{31}$.

\section{Discussion}

The synchronicity of millennial-scale climate shifts in the North Atlantic, China and Flores demonstrates that displacements of the entire Australasian monsoon system can occur within decades. The interhemispheric precipitation seesaw pattern defined by the China and Flores stalagmite $\delta^{18} \mathrm{O}$ records is likely related to latitudinal shifts in the mean position of the ITCZ in response to Northern Hemisphere temperature change ${ }^{1,5,8,9}$. Notably, the records show that the HS1 interval is the most prominent and longest of these millennial-scale events in Australasia. A protracted southward migration of the Australasian monsoon system during HS1 is consistent with weak Atlantic meridional overturning circulation, expansion of Northern Hemisphere sea-ice and intensely cold northern winters $^{1,5}$. We note that the emerging pattern of climatic impacts for the HS1 interval in Australasia does not resemble the zonal climatic footprint of the El Niño-Southern Oscillation. Borneo $\left(4^{\circ} \mathrm{N}\right)$ and Flores $\left(9^{\circ} \mathrm{S}\right)$, for example, are subject to the same El Niño climatic impacts ${ }^{32}$, yet their stalagmite $\delta^{18} \mathrm{O}$ response to the HS1 interval is anti-correlated. Instead, the rainfall increase evident in the Flores stalagmite record, and other terrestrial hydroclimate records for southern Indonesia ${ }^{23}$, southern Papua New Guinea ${ }^{22}$ and northern Australia ${ }^{19,20,24}$, indicate that steepening of the north-south interhemispheric thermal gradient during HS1 produced a strong southward shift of the Australasian monsoon.

The interhemispheric seesaw pattern of Australasian monsoon climate on millennial-scales lends support to the possibility that a protracted southward displacement of the global monsoon system during an intensely cold HS1 may have been an integral part of the sequence of events driving the last deglaciation ${ }^{5}$. Increasing boreal summer insolation acting on exceptionally large and unstable Northern Hemisphere ice sheets and ice-albedo feedbacks are considered to be the fundamental initiators of ice age terminations $\mathrm{s}^{33,34}$. During the last deglaciation, northern ice sheet recession was underway by $\sim 20-19 \mathrm{kyr} \mathrm{BP}{ }^{34}$. The Flores $\delta^{18} \mathrm{O}$ record shows a significant northward shift of the AISM around 19-18 kyr BP (Fig. 4) that may reflect warming in the North Atlantic prior to the onset of HS1 (ref. 31). Incipient reinvigoration of the Atlantic meridional overturning circulation and the bipolar seesaw at this time is indicated by terrestrial and ocean proxies showing North Atlantic warming ${ }^{31,35}$ and highlatitude Southern Hemisphere cooling ${ }^{3,36-38}$ (Fig. 4). The subsequent intensity and length of the HS1 interval, and southward displacement of the monsoon and southern westerly windbelts ${ }^{2,8-10}$, ventilated sufficient $\mathrm{CO}_{2}$ from deep Southern Ocean waters to produce global warming ${ }^{11,39}$. The Flores $\delta^{18} \mathrm{O}$ record confirms that the deglacial rise in atmospheric $\mathrm{CO}_{2}$ stalled

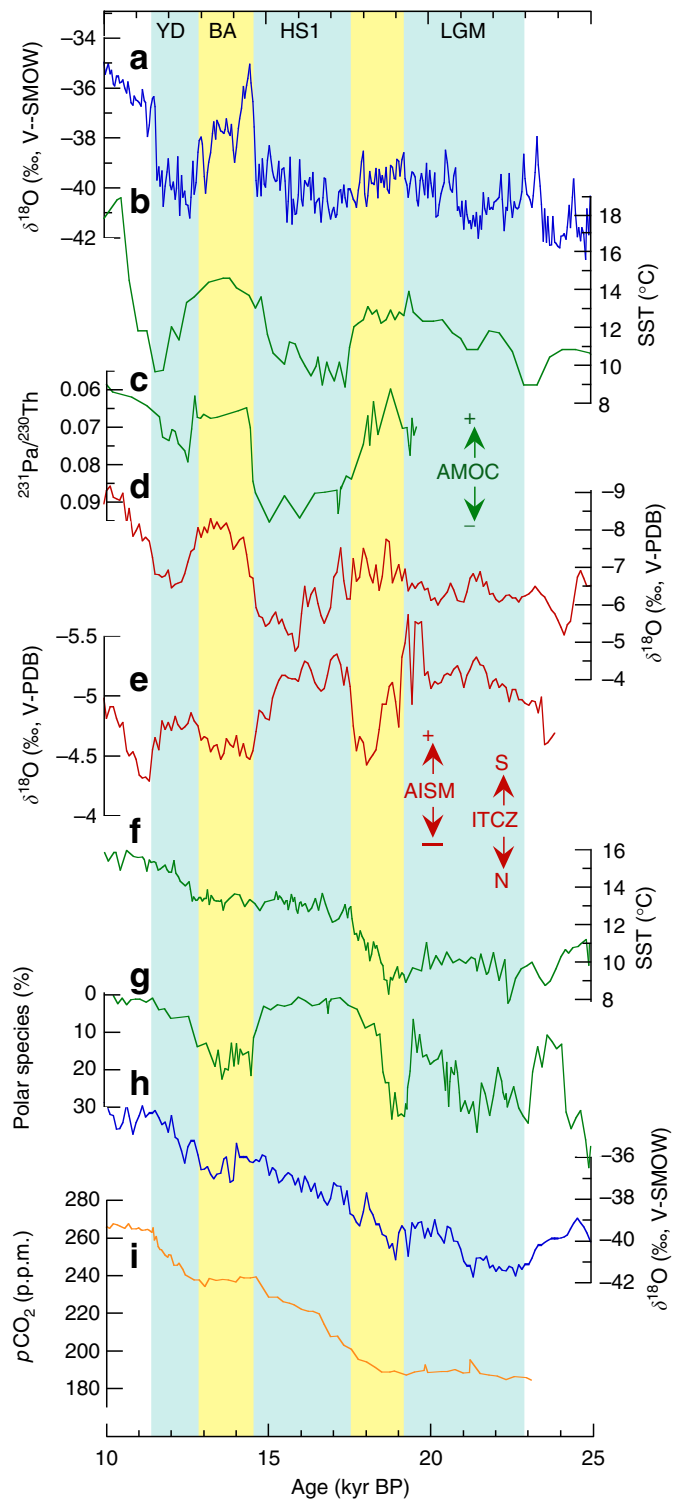

Figure 4 | Comparison of palaeoclimate records over the last deglaciation. (a) $\delta^{18} \mathrm{O}$ in the Greenland Ice Sheet Project 2 (GISP2) ice core $^{35}$; (b) SST reconstructed from alkenone unsaturation ratios in North Atlantic marine sediment core SU-8118 $8^{31}$; (c) ${ }^{231} \mathrm{~Pa} /{ }^{230} \mathrm{Th}$ (as an overturning circulation proxy) in marine sediment core GGC5 near the Bermuda Rise, North Atlantic ${ }^{53}$ (arrow depicts the direction of a stronger $(+)$ or weaker $(-) \mathrm{AMOC}$ ). (d) composite stalagmite $\delta^{18} \mathrm{O}$ record for Hulu12,47,48 and Dongge ${ }^{13}$ caves, China; (e) composite stalagmite $\delta^{18} \mathrm{O}$ record for Flores (arrows depict the direction of a stronger $(+)$ or weaker ( - ) AISM and southward (S) or northward (N) movement of the ITCZ); (f) alkenone-based SST record for ODP core 1233 in the southeast Pacific off southern Chile ${ }^{38}$; (g) polar foraminiferal species abundance in marine sediment core TN057-21 from the South Atlantic sector of the Southern Ocean ${ }^{3} ;(\mathbf{h}) \delta^{18} \mathrm{O}$ in the low-elevation Byrd Station Antarctica ice core ${ }^{36}$; and (i) atmospheric $\mathrm{CO}_{2}$ concentrations in the EPICA Dome C Antarctica ice core ${ }^{39}$. The EPICA Dome $C$ and Byrd ice core records are plotted on the GISP2 timescale ${ }^{37,54}$. The Flores stalagmite $\delta^{18} \mathrm{O}$ record indicates southward shifts of the AISM during the LGM, HS1 and YD (blue shading) and northward shifts of the AISM during the 19.5-17.6 kyr BP interval and B-A (yellow shading).

along with northward monsoon displacement during the warmer Bølling-Allerød interval and resumed with southward monsoon displacement during the cooler Younger Dryas. 
Our findings demonstrate the interhemispheric extent of millennial-scale climate change during the last deglaciation and show that the entire Australasian monsoon system responded rapidly to climate events in the northern high latitudes. The large size and climatic sensitivity of Australasia support the idea of a key role for the global monsoon in the oceanic/atmospheric set of events leading to rising atmospheric $\mathrm{CO}_{2}$ concentrations and global warming during ice age terminations. While model-based tests are required to quantify monsoon feedbacks on global climate, our data are consistent with the view that high-latitude and low-latitude climate processes are inextricably linked. The Australasian precipitation seesaw pattern identified here may help guide the development of models to predict rainfall patterns in this critical region, which houses nearly two-thirds of the global population.

\section{Methods}

${ }^{230}$ Th dating. Chronologies for stalagmites LR06-B3, LR06-C2, LR06-C3, LR06C5 and LR06-C6 were constructed from $86{ }^{230} \mathrm{Th}$ dates determined by thermal ionization mass spectrometry at the University of Queensland and multi-collector inductively coupled plasma mass spectrometry at the University of Melbourne. The thermal ionization mass spectrometry and multi-collector inductively coupled plasma mass spectrometry analytical protocols used to determine the ${ }^{230} \mathrm{Th}$ ages for the five stalagmites (Supplementary Table S1) are outlined in refs 40 and 41. Decay constants for ${ }^{230} \mathrm{Th}\left(75,690 \pm 230\right.$ years) and ${ }^{234} \mathrm{U}(245,250 \pm 490$ years $)$ used in the age calculations are those of ref. 42.

Samples for dating were either small prisms cut adjacent to the stable isotope sampling transects, or splits of the powders used for stable isotope analysis. The samples varied from 2 to $10 \mathrm{~mm}$ in length along the central growth axis, and from 30 to $1200 \mathrm{mg}$ in weight. Age-depth models were calculated for each stalagmite using the line-of-best-fit through the ${ }^{230} \mathrm{Th}$ ages after correction for small amounts of detrital ${ }^{230} \mathrm{Th}$ (Supplementary Figs S1-S5).

Stratigraphical constraints modelling ${ }^{43}$ to determine the detrital $\left[{ }^{230} \mathrm{Th} /\right.$ $\left.{ }^{232} \mathrm{Th}\right]_{\text {initial }}$ for the Liang Luar stalagmites was undertaken by Griffiths et al. ${ }^{26}$. Stalagmite LR06-B1 investigated in ref. 26 has the highest temporal frequency of ${ }^{230} \mathrm{Th}$ dates of any specimen investigated from Liang Luar. It grew over the last $\sim 13 \mathrm{kyr}$ and is therefore highly sensitive to detrital ${ }^{230} \mathrm{Th}$ contamination, thus it constitutes the best material to determine the detrital $\left[{ }^{230} \mathrm{Th} /{ }^{232} \mathrm{Th}\right]_{\text {initial }}$ value for Liang Luar cave. We therefore considered that the calculated $\left[{ }^{230} \mathrm{Th} /{ }^{232} \mathrm{Th}\right]_{\text {initial }}$ value of $7 \pm 2$ (ref. 26) was the most appropriate one to apply to the new stalagmite $\delta^{18} \mathrm{O}$ records presented here, rather than the 'generic' crustal value of $0.82 \pm 0.41$, which is used by convention when no other information is available. Detrital ${ }^{230} \mathrm{Th}$ contamination of the Liang Luar stalagmite samples was generally very low giving average precisions of $\pm 0.9 \%(2 \sigma)$ for ${ }^{230} \mathrm{Th}$ ages $>10 \mathrm{kyr} \mathrm{BP}$ after slight corrections (Supplementary Table S1).

Stable isotope analysis. Samples for stable isotope analysis were milled continuously at $2-10-\mathrm{mm}$ intervals along grooves positioned on the central growth axis of each stalagmite, corresponding to an average of $\sim 80$ years of growth (Supplementary Table S3). Sample powders $(\sim 200 \mu \mathrm{g})$ were analysed for $\delta^{18} \mathrm{O}$ at the Australian National University on a Finnigan MAT-251 mass spectrometer equipped with an automated Kiel carbonate reaction device. $\mathrm{CO}_{2}$ was liberated from the carbonate by reaction under vacuum with $105 \% \mathrm{H}_{3} \mathrm{PO}_{4}$ at $90{ }^{\circ} \mathrm{C}$, and calibrated against NBS-19 and NBS-18. The analytical precision of $\delta^{18} \mathrm{O}$ measurements for aliquots of NBS-19 run in parallel with the stalagmite samples was $\pm 0.03 \%$ o $(1 \sigma, n=335$. Replicate aliquots of sample powders for LR06-B3 and LR06-C6 were analysed to check for homogeneity (Supplementary Fig. S6).

Equilibrium precipitation of oxygen isotopes. The most robust test of precipitation of stalagmite carbonate under oxygen isotopic equilibrium conditions is replication of contemporaneous stalagmite $\delta^{18} \mathrm{O}$ records. This is because the chance of obtaining identical $\delta^{18} \mathrm{O}$ records from two or more stalagmites (with unique drip water sources and $\mathrm{CO}_{2}$ degassing histories) that are the product of disequilibrium offsets (for example, kinetic fractionation ${ }^{44}$ ) is extremely low. The individual stalagmite $\delta^{18} \mathrm{O}$ records for Liang Luar presented here and in previous studies $^{26,27}$ agree remarkably well for most of the last $25 \mathrm{kyr}$ (Fig. 2). Another demonstration of absence of kinetic fractionation of stable isotopes in the Liang Luar stalagmites is given by the insignificant correlation between their $\delta^{18} \mathrm{O}$ and $\delta^{13} \mathrm{C}$ values (Supplementary Fig. S7).

The section of the $\delta^{18} \mathrm{O}$ record for stalagmite LR06-C5 containing 22-66\% aragonite between 19.4 and $17.5 \mathrm{kyr}$ BP was corrected to magnesium calciteequivalent $\delta^{18} \mathrm{O}$ values (Supplementary Fig. S8, Supplementary Tables S2 and S3). Aragonite contents were determined by quantitative X-ray diffraction analysis. The record across the aragonitic interval was then corrected using aragonitemagnesium calcite enrichment factors of $+0.7 \%$ for $\delta^{18} \mathrm{O}$ (and $+2.5 \%$ for $\delta^{13} \mathrm{C}$ as required for Supplementary Fig. S7) (refs 45 and 46). The carbonate structure of
LR06-C5 between 19.4 and $17.5 \mathrm{kyr}$ BP comprises fine laminae of primary magnesium calcite and aragonite so it is unlikely that the $\delta^{18} \mathrm{O}$ signals have been affected significantly by isotope fractionation or recrystallization processes. The $\delta^{18} \mathrm{O}$ records for stalagmites LR06-C5 (corrected to magnesium calcite-equivalent values) and LR06-C6 are in good agreement across their interval of overlap (Supplementary Fig. S6). Together, the results suggest that the aragonitic section of LR06-C5 has retained primary $\delta^{18} \mathrm{O}$ signals, and that the corrections applied to the mixed aragonite/magnesium calcite $\delta^{18} \mathrm{O}$ values are valid.

Construction of the composite $\boldsymbol{\delta}^{\mathbf{1 8}} \mathbf{O}$ record for Flores. The $\delta^{18} \mathrm{O}$ time-series for each Liang Luar stalagmite was resampled at 100 -year resolution to produce a composite $\delta^{18} \mathrm{O}$ record for Flores. $\delta^{18} \mathrm{O}$ values for replicate analysis of samples for stalagmites LR06-B3 and LR06-C6 were averaged for inclusion in the $\delta^{18} \mathrm{O}$ timeseries. The corrected $\delta^{18} \mathrm{O}$ values for the aragonitic section of stalagmite LR06-C5 (corrected to magnesium calcite-equivalent values) were included in the composite. The final $\delta^{18} \mathrm{O}$ time-series were averaged to produce the composite $\delta^{18} \mathrm{O}$ record (with 95\% confidence limits across intervals of overlap) shown in Supplementary Fig. S11a and summarized in Supplementary Table S4. We performed the same analysis for the Hulu ${ }^{12,47,48}$ and Dongge ${ }^{13}$ cave stalagmite $\delta^{18} \mathrm{O}$ records to produce a composite $\delta^{18} \mathrm{O}$ record for China (Supplementary Fig. S11b) for comparison with the Liang Luar record and other palaeoclimate records in Fig. 4.

Data archiving. The ${ }^{230} \mathrm{Th}$ age-depth models and $\delta^{18} \mathrm{O}$ data for the Liang Luar stalagmites are archived at the NOAA World Data Center for Paleoclimatology at http://www.ncdc.noaa.gov/paleo/data.html.

\section{References}

1. Denton, G. H., Alley, R. B., Comer, G. C. \& Broecker, W. S. The role of seasonality in abrupt climate change. Quat. Sci. Rev. 24, 1159-1182 (2005).

2. Anderson, R. F. et al. Wind-driven upwelling in the Southern Ocean and the deglacial rise in atmospheric $\mathrm{CO}_{2}$. Science 323, 1443-1448 (2009).

3. Barker, S. et al. Interhemispheric Atlantic seesaw response during the last deglaciation. Nature 457, 1097-1103 (2009).

4. Cheng, H. et al. Ice age terminations. Science 326, 248-252 (2009).

5. Denton, G. H. et al. The last glacial termination. Science 328, 1652-1656 (2010).

6. De Deckker, P., Moros, M., Perner, K. \& Jansen, E. Influence of the tropics and southern westerlies on glacial interhemispheric asymmetry. Nat. Geosci. $\mathbf{5}$, 266-269 (2012).

7. Putnam, A. E. et al. The Last Glacial Maximum at $44^{\circ} \mathrm{S}$ documented by a ${ }^{10} \mathrm{Be}$ moraine chronology at Lake Ohau, Southern Alps of New Zealand. Quat. Sci. Rev. 62, 114-141 (2013).

8. Chiang, J. C. \& Bitz, C. M. Influence of high latitude ice cover on the marine intertropical convergence zone. Clim. Dynam. 25, 248-252 (2005).

9. Broccoli, A. J., Dahl, K. A. \& Stouffer, R. J. Response of the ITCZ to northern hemisphere cooling. Geophys. Res. Lett. 33, L01702 (2006).

10. Toggweiler, J. R., Russell, J. L. \& Carson, S. R. Midlatitude westerlies, atmospheric $\mathrm{CO}_{2}$, and climate change during the ice ages. Paleoceanography 22, PA2210 (2006).

11. He, F. et al. Northern Hemisphere forcing of Southern Hemisphere climate during the last deglaciation. Nature 494, 81-85 (2013).

12. Wang, Y. J. et al. A high-resolution absolute-dated late Pleistocene monsoon record from Hulu Cave, China. Science 294, 2345-2348 (2001).

13. Yuan, D. et al. Timing, duration, and transitions of the last interglacial Asian monsoon. Science 304, 575-578 (2004).

14. Partin, J. W., Cobb, K. M., Adkins, J. F., Clark, B. \& Fernandez, D. P. Millennial-scale trends in west Pacific warm pool hydrology since the Last Glacial Maximum. Nature 449, 452-455 (2007).

15. Carolin, S. A. et al. Varied response of Western Pacific hydrology to climate forcings over the Last Glacial period. Science 340, 1564-1566 (2013).

16. Wang, X. F. et al. Wet periods in northeastern Brazil over the past $210 \mathrm{kyr}$ linked to distant climate anomalies. Nature 432, 740-743 (2004).

17. Kanner, L. C., Burns, S. J., Cheng, H. \& Edwards, R. L. High-latitude forcing of the South American summer monsoon during the last glacial. Science 335, 570-573 (2012).

18. Stager, J. C., Ryves, D. B., Chase, B. M. \& Pausata, F. S. R. Catastrophic drought in the Afro-Asian monsoon region during Heinrich Event 1. Science 331, 1299-1302 (2011).

19. Turney, C. S. M. et al. Millennial and orbital variations of El Niño/Southern Oscillation and high-latitude climate in the last glacial period. Nature 428, 306-310 (2004).

20. Muller, J. et al. Possible evidence for wet Heinrich phases in tropical NE Australia: the Lynch's Crater deposit. Quat. Sci. Rev. 27, 468-475 (2008).

21. Mohtadi, M. et al. Glacial to Holocene swings of the Australian-Indonesian monsoon. Nat. Geosci. 4, 540-544 (2011).

22. Shiau, L.-J. et al. Warm pool hydrological and terrestrial variability near southern Papua New Guinea over the past 50k. Geophys. Res. Lett. 38, L00F01 (2011). 
23. Muller, J., McManus, J. F., Oppo, D. W. \& Francois, R. Strengthening of the Northeast Monsoon over the Flores Sea, Indonesia, at the time of Heinrich event 1. Geology 40, 635-638 (2012).

24. Denniston, R. F. et al. North Atlantic forcing of millennial-scale IndoAustralian monsoon dynamics during the Last Glacial period. Quat. Sci. Rev. 72, 159-168 (2013).

25. Meckler, A. N., Clarkson, M. O., Cobb, K. M., Sodemann, H. \& Adkins, J. F. Interglacial hydroclimate in the tropical west Pacific through the Late Pleistocene. Science 336, 1301-1304 (2012).

26. Griffiths, M. L. et al. Increasing Australian-Indonesian monsoon rainfall linked to early Holocene sea-level rise. Nat. Geosci. 2, 636-639 (2009).

27. Lewis, S. C. et al. High-resolution stalagmite reconstructions of AustralianIndonesian monsoon rainfall variability during Heinrich stadial 3 and Greenland interstadial 4. Earth Planet. Sci. Lett. 303, 133-142 (2011).

28. Linsley, B. K., Rosenthal, Y. \& Oppo, D. W. Holocene evolution of the Indonesian throughflow and the western Pacific warm pool. Nat. Geosci. 3, 578-583 (2010).

29. Cruz, F. W. et al. Insolation-driven changes in atmospheric circulation over the past 116,000 years in subtropical Brazil. Nature 434, 63-66 (2005).

30. DiNezio, P. N. \& Tierney, J. E. The effect of sea level on glacial Indo-Pacific climate. Nat. Geosci. 6, 485-491 (2013).

31. Bard, E., Rostek, F., Turon, J.-L. \& Gendreau, S. Hydrological impact of Heinrich events in the subtropical northeast Atlantic. Science 289, 1321-1324 (2000).

32. Dai, A. \& Wigley, T. M. L. Global patterns of ENSO-induced precipitation. Geophys. Res. Lett. 27, 1283-1286 (2000).

33. Raymo, M. E. The timing of major climate terminations. Paleoceanography 12, 577-585 (1997)

34. Clark, P. U. et al. The last glacial maximum. Science 325, 710-714 (2009).

35. Stuiver, M. \& Grootes, P. M. GISP2 oxygen isotope ratios. Quat. Res. 53, 277-283 (2000)

36. Johnsen, S. J., Dansgaard, W., Clausen, H. B. \& Langway, C. C. Oxygen isotope profiles through the Antarctic and Greenland ice sheets. Nature 235, 425-434 (1972).

37. Blunier, T. \& Brook, E. J. Timing of millennial-scale climate change in Antarctica and Greenland during the last glacial period. Science 291, 109-112 (2001).

38. Lamy, F. et al. Modulation of the bipolar seesaw in the Southeast Pacific during Termination 1. Earth Planet. Sci. Lett. 259, 400-413 (2007).

39. Monnin, E. et al. Atmospheric $\mathrm{CO}_{2}$ concentrations over the last glacial termination. Science 291, 112-114 (2001).

40. Zhao, J. X., Xia, Q. K. \& Collerson, K. D. Timing and duration of the Last Interglacial inferred from high resolution U-series chronology of stalagmite growth in the Southern Hemisphere. Earth Planet. Sci. Lett. 184, 635-644 (2001).

41. Hellstrom, J. Rapid and accurate U/Th dating using parallel ion-counting multi-collector ICP-MS. J. Anal. Atom. Spectrom. 18, 1346-1351 (2003).

42. Cheng, H. et al. The half-lives of uranium-234 and thorium-230. Chem. Geol. 169, 17-33 (2000)

43. Hellstrom, J. U-Th dating of speleothems with high initial ${ }^{230} \mathrm{Th}$ using stratigraphical constraint. Quat. Geochron. 1, 289-295 (2006).

44. Hendy, C. H. The isotopic geochemistry of speleothems - The calculation of the effects of different modes of formation on the isotopic composition of speleothems and their applicability as palaeoclimatic indicators. Geochim. Cosmochim. Acta 35, 801-824 (1971).
45. Kim, S.-T., O’Neil, J. R., Hillaire-Marcel, C. \& Mucci, A. Oxygen isotope fractionation between synthetic aragonite and water: influence of temperature and $\mathrm{Mg}+$ concentration. Geochim. Cosmochim. Acta 71, 4704-4715 (2007).

46. Morse, J. \& Mackenzie, F. Geochemistry of Sedimentary Carbonates. Developments in Sedimentology, Vol. 48 (Elsevier, Amsterdam, 1990).

47. Wu, J. Y., Wang, Y. J., Cheng, H. \& Edwards, L. R. An exceptionally strengthened East Asia summer monsoon event between 19.9 and $17.1 \mathrm{ka} \mathrm{BP}$ recorded in a Hulu stalagmite. Sci. China Ser. D. 52, 360-368 (2009).

48. Southon, J., Noronha, A. L., Cheng, H., Edwards, R. L. \& Wang, Y. A high resolution record of atmospheric ${ }^{14} \mathrm{C}$ based on Hulu cave speleothem H82. Quat. Sci. Rev. 33, 32-41 (2012).

49. Wallace, J. M., Mitchell, T. P. \& Lau, K.-H. Legates/MSU Precipitation Climatology, http://www.jisao.washington.edu/legates_msu/ (1995).

50. Legates, D. R. \& Willmott, C. J. Mean seasonal and spatial variability in gaugecorrected global precipitation. Int. J. Climatol. 10, 111-127 (1990).

51. Spencer, R. W. Global oceanic precipitation from the MSU during 1979-91 and comparisons to other climatologies. J. Clim. 6, 1301-1326 (1993).

52. Bintanja, R. \& van de Wal, R. S. W. North American ice-sheet dynamics and 100,000-year glacial cycles. Nature 454, 869-872 (2008).

53. McManus, J. F., Francois, R., Gherardi, J.-M., Keigwin, L. D. \& Brown-Leger, S Collapse and rapid resumption of Atlantic meridonal circulation linked to deglacial climate changes. Nature 428, 834-837 (2004).

54. Marchitto, T. M., Lehman, S. J., Ortiz, J. D., Flückiger, J. \& van Geen, A. Marine radiocarbon evidence for the mechanism of deglacial atmospheric $\mathrm{CO}_{2}$ rise. Science 316, 1456-1459 (2007).

\section{Acknowledgements}

We thank the Indonesian Institute of Sciences (LIPI) for logistical and technical support in the field; J. Cali for stable isotope laboratory support; D. Qu, Y. Feng, G. Mortimer and M. McCulloch for U-series laboratory support; U. Troitzch for XRD analyses; J. Cali and B. Ferguson for specimen photography; G. Smith for providing the thumbnail photograph; the staff of K\&D Stonemasons for help with stalagmite sectioning; N. Anderson and G. Smith for expert caving support and the people of Rampasasa village, Flores for assistance in the field. The work was carried out under LIPI Research Permit number 04057/SU/KS/2006 and funded by Australian Research Council Discovery grants DP0663274 and DP1095673 to M.K.G., R.N.D., J.-x.Z., J.C.H. and W.S.H.

\section{Author contributions}

L.K.A., J.A.C. and H.S-G. performed the microsampling and stable isotope analyses. J.-x.Z., J.C.H. and E.St P. were responsible for U-Th dating. W.S.H. and B.W.S. arranged official research permits and led logistical support for the fieldwork. M.K.G., L.K.A, R.N.D., J.-x.Z., M.L.G. and H.S-G. wrote the paper.

\section{Additional information}

Supplementary Information accompanies this paper at http://www.nature.com/nature communications.

Competing financial interests: The authors declare no competing financial interests

Reprints and permission information is available online at http://npg.nature.com/ reprintsandpermissions/

How to cite this article: Ayliffe, L. K. et al. Rapid interhemispheric climate links via the Australasian monsoon during the last deglaciation. Nat. Commun. 4:2908 doi: 10.1038/ ncomms3908 (2013). 